\title{
Modelling Lockean Legalism in the Executive Emergency Power on Environment and Climate Change Domain in Malaysia
}

Mazlina Mohamad Mangsor, Norazlina Abdul Aziz, Nur Ezan Rahmat \& Ainul Hafizah Zainudin

To Link this Article: http://dx.doi.org/10.6007/IJARBSS/v11-i5/10032

DOI:10.6007/IJARBSS/v11-i5/10032

Received: 01 March 2021, Revised: 05 April 2021, Accepted: 27 April 2021

Published Online: 20 May 2021

In-Text Citation: (Mangsor et al., 2021)

To Cite this Article: Mangsor, M. M., Aziz, N. A., Rahmat, N. E., \& Zainudin, A. H. (2021). Modelling Lockean Legalism in the Executive Emergency Power on Environment and Climate Change Domain in Malaysia. International Journal of Academic Research in Business and Social Sciences, 11(5), 774-784.

\section{Copyright: (c) 2021 The Author(s)}

Published by Human Resource Management Academic Research Society (www.hrmars.com) This article is published under the Creative Commons Attribution (CC BY 4.0) license. Anyone may reproduce, distribute, translate and create derivative works of this article (for both commercial and non-commercial purposes), subject to full attribution to the original publication and authors. The full terms of this license may be seen at: http://creativecommons.org/licences/by/4.0/legalcode

Vol. 11, No. 5, 2021, Pg. 774 - 784

Full Terms \& Conditions of access and use can be found at http://hrmars.com/index.php/pages/detail/publication-ethics 


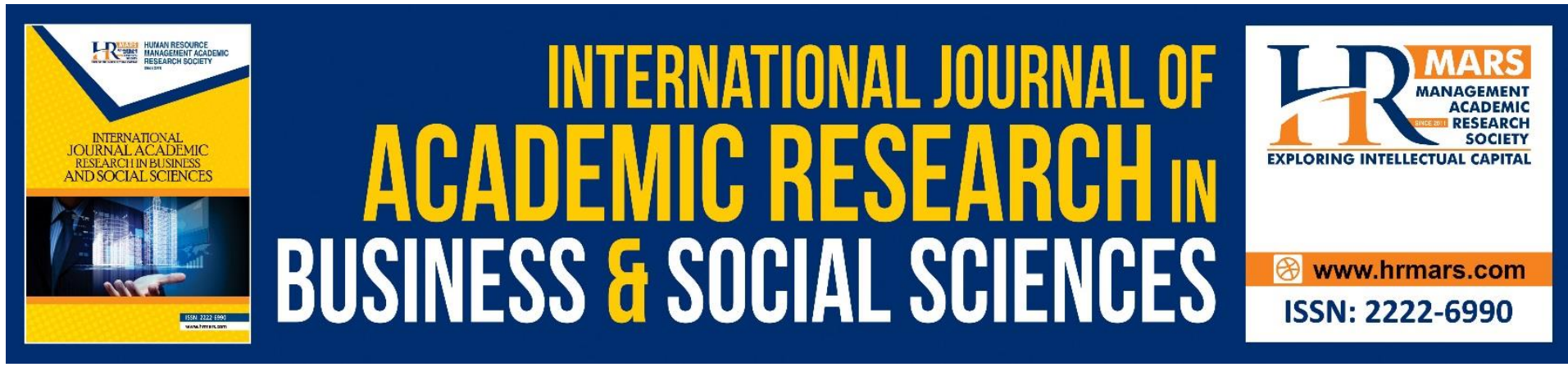

\title{
Modelling Lockean Legalism in the Executive Emergency Power on Environment and Climate Change Domain in Malaysia
}

\author{
Mazlina Mohamad Mangsor, Norazlina Abdul Aziz, Nur Ezan \\ Rahmat \& Ainul Hafizah Zainudin \\ Senior Lecturers Faculty of Law, Universiti Teknologi MARA, \\ 40450 Shah Alam, Selangor, Malaysia
}

\begin{abstract}
Human rights activists demanded a stringent action from the Executive due to an annual occurrence of river pollution and a recurring haze disaster in 2019. The proposed move includes removal of the respective Environment Minister and an emergency declaration by the King (YDPA) to address the above situations. It is under this premise that the Lockean legalism model is explored in relation to the emergency power conferred to the Executive i.e., the Monarch. Modelling John Locke's legalism, namely conditions of political legitimacy meaningfully describe legitimate sovereign approach to laws that are conducive to public good. The primary aim of the research is to legally explore the adoption of Lockean legalism in examining the extent of the powers conferred to the YDPA and the enumerated function of the Conference of Rulers in the proclamation of emergency in the environment and climate change domain in Malaysia. The research employs a qualitative methodology and incorporates a content analysis approach. The outcome of this study is a proposed measure using the Lockean mechanism in understanding the power to proclaim emergency in the environmental crisis. This research is significant as it would contribute to the body of knowledge to enhance the prerogative power of the YDPA in relation to the state of emergency.
\end{abstract}

Keywords: Emergency Power, YDPA, Prerogative, Environment, Locke

\section{Introduction}

In 2019 , the Sungai Kim Kim pollution has affected more than 20,000 people and the closing of 475 education institutions in the state of Johor. In addition, transboundary smoke haze has also caused a nearly similar environmental crisis nationwide including respiratory illness and other health hazards. The Malaysian Parliament passed a motion to announce emergency over the Sungai Kim Kim incident but was turned a deaf ear by the Executive.

Declaration of state of emergency is made when the nation experiences some sort of volatility or as specifically described in the Federal Constitution, when the security, economic life or national peace is at stake. The power to declare a state of emergency vested on the Yang diPertuan Agong (YDPA) and this power of the YDPA may be exercised if he is convinced and satisfied that "a grave emergency exists" (Article 150(1), Federal Constitution). This 
enumerated function of His Majesty Executive power has experienced many revolutions that in some instances has challenged His Royal Highness sole position to proclaim state of emergency and in some other instances has expanded the interpretation given to the meaning of "a grave emergency exists". In performing His Majesty's function, the provision is interpreted into two dominant arguments, they are YDPA acting on advice and YDPA officially declaring an emergency without any advice from the Prime Minister (PM).

\section{Lockean Legalism Model}

Considering the above legal and constitutional development, the research recommends that the power to proclaim emergency by His Majesty is at an ambiguous status. The Lockean legalism model suggests the notion that all political action i.e., the Executive must serve the public good (Locke, 1988; Sharon, 2019). The proposed initiative is to adopt the Lockean peace, safety, and public good parameters within which the constitutional monarchy system consists of the emergency powers of the YDPA in the environment and climate change domain in Malaysia.

John Locke's theory cherishes the Executive with a prerogative power to make exceptional decisions in emergencies (Jenkins, 2011). The Executive discretion is permitted when the consequences of observance to law are grave enough to outweigh the inevitable cost of violating it (Sharon, 2019). This situation exists in an emergency although from Locke's perspective nothing importantly special about them.

The Lockean model highlights the Executives' role within a limited government regime and regards the bounds of their legitimacy as a promotion of the public good (Sharon, 2019). Nurturing public good and protecting property become the grounds for the Executive prerogative and may reach extra-legal, beyond the constitutional command (Locke, 1988). Despite this liberal approach, Locke emphasised on "established standing laws, promulgated and known to the people" (Locke,1988) within which is generally favorable to the public good, as it tends to limit abuses of power and allows citizens to form dependable expectations about the outcomes of their actions (Sharon, 2019).

Thus, this study aims to critically examine the Lockean legalism approach on the significant role of the Executive, particularly the emergency powers of His Majesty in the proclamation of emergency and the function of the Conference of Rulers to safeguard public safety. The research will only lightly analyse issues involving the Sungai Kim Kim victims' actions including the latest where they have filed RM30mil suit against Federal, state government and ten others and the trial is still ongoing (Devi, 2019).

\section{Method}

This research employed a qualitative method and adopted a content analysis approach using the Lockean legalism model. The normative aspects of the respective legislation are analysed. They are primary and secondary sources through the library-based research. Whilst the first encompasses of Malaysian legislation, policies and judicial decisions, the latter constitutes a significant proportion of online databases including LexisNexis, Malayan Legal Journal, and others. The former data are based on the legal cases and legislative framework for the state of emergency related to the power of YDPA, Conference of Rulers, Parliament and the PM involving provisions of the Malaysian Federal Constitution and the National Security Council Act 2016.

Theories and models of government system ranges from divine rights absolutism (Bossuet, 1707), philosophical absolutism (Hobbes, 1651), philosophical and biblical constitutionalism 
(Locke, 1988) to the first modern idea of total separation of powers (Cohler, Miller and Stone, 1989). Locke's notion of separation of powers is enhanced with the doctrine of prerogative. Locke's understanding on prerogative power significantly contributed to the research on the monarchy power during emergency and extensively used as theoretical framework in prerogative studies. Arnold (2005); Tushnet (2005); Jenkins (2011); Sharon (2019) critically highlighted that the King's prerogative according to Lockean will empower the monarchy position beyond parameter of the law. The Malaysian Federal Constitution provisions are analysed based on the Lockean primary features of institutional separation, executive discretionary power, ruler prerogative, purpose for public good, public evaluation and extraconstitutional method (Locke, 1988). Fig.1 below illustrates the mapping of the Lockean main features to the Malaysian Federal Constitution. Provisions related to the YDPA emergency powers are examined based on the Lockean model.

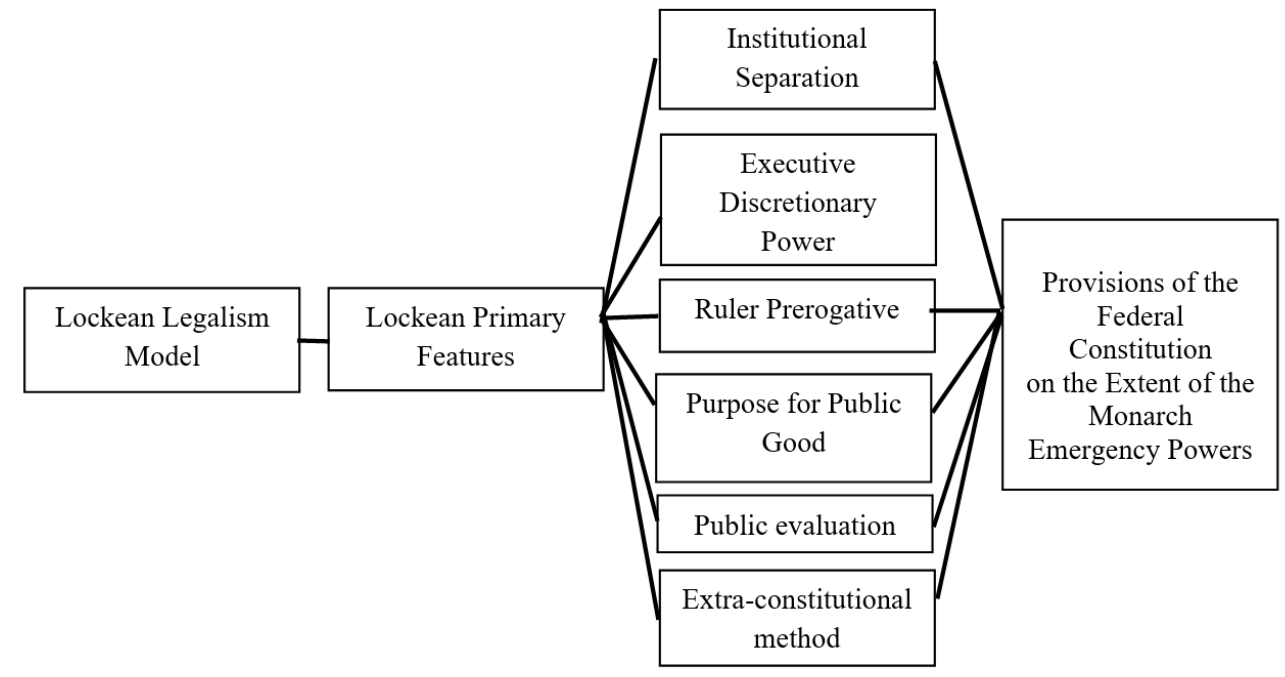

Fig.1: The mapping of the Lockean features to the Federal Constitution

\section{Results and Discussion}

Monarchy in Malaysia has prevailed in its native mint because to a large extent, the rulers and their subjects have endeavored to preserve its sanctity. There is some wisdom in an institution that is one so old. Malaysia adopts a constitutional monarchy in a parliamentary democracy system (Bulmer, 2017). Whilst, it has a bicameral structure at federal level with the King (YDPA) as the head of state and the PM as the head of government, the state level composition is a unicameral system with the Ruler as the head of state and the Chief Minister (Menteri Besar) as the head of the state government. The hereditary state ruler is known as Sultan, Raja or Yang di-Pertuan Besar and states without a ruler will appoint the Yang diPertua Negeri (The Star, 2010). In short, the focus of the research is the executive at the federal level, they are the Conference of Rulers, the YDPA, the PM and the Cabinet Members.

\section{The Meaning of Emergency}

The constitutional description of an emergency is embedded in the power conferred to the YDPA. The Federal Constitution provides the following:

If the Yang di-Pertuan Agong is satisfied that a grave emergency exists whereby the security, or the economic life, or public order in the Federation or any part thereof is threatened, he may issue a Proclamation of Emergency making therein a declaration to that effect. (Article 150). 
The power to proclaim emergency by the YDPA under Article 150(1) of the Federal Constitution requires the Monarch to consider and to satisfy a "grave emergency exist". Article 40(2) enhances the YDPA discretionary power in the relation to "any other case mentioned in this Constitution".

Vern (2019) connoted the following meaning of a state of emergency:

An exceptional situation where a government or public authority is empowered due to extraordinary circumstances presenting an urgent threat to the existing order- to apply special measures that it would not otherwise be permitted to use, in order to confront these circumstances. (p. Ixxv).

The judiciary in the case of Stephen Kalong Ningkan $v$ Abang Openg (1968) widened the scope of emergency to include diverse elements such as wars, famines, earthquake, floods, epidemics, and the collapse of civil government. This definition may encapsulate the environment and climate change domain in Malaysia within which deals with the issues of air and river pollution hazards. However, there is no clear directive in the exercise of the emergency power by the YDPA on the environment and climate change domain.

Interpretations of "a grave emergency exists" in the earlier days were confined to communist threats and protests that led to the declaration of state of emergency in 1948, 1964 and the racial riots in 1969. The ground for declaration of emergency in Sarawak in 1966 and Kelantan in 1977, Kelantan were similar. The justification of "threat and grave situation" that led to the proclamation of emergency was due to the refusal of the head of government to resign. These states of emergency were terminated in 2011 and the extensive powers are embedded in the Federal Constitution with the possibility of instilling an authoritarian rule (Vern, 2019).

This trend revolves further in these recent years when the government had considered proclaiming a state of emergency due to excessive heat, massive flood in Kelantan and severe environmental pollution of haze and intoxicated air. The declaration of emergency in Kuala Selangor and Port Klang in 2005 as well as in Muar and Ledang in 2013 due to a severe haze reflected a different approach dealing with a disaster emergency. In 2019, the Sungai Kim chemical dumping incident led the Dewan Rakyat to approve a motion to declare a state of emergency (Carvalho et al., 2019) but Putrajaya i.e., the Executive refused to honour the Parliament (Annuar, 2019)

\section{The Nature of Prerogative and Emergency Power}

Literally Article 150(1) provides an interpretation of a sole discretionary power of His Royal Highness to signify the declaration of emergency, but the standing of Malaysian court in many cases are directed to the opinion that the declaration of emergency by the YDPA is a nondiscretionary power to be exercised on advice of the PM. In the case of Teh Cheng Poh $v$ Public Prosecutor (1979) the judiciary highlighted that the term "satisfaction" under Article 150(1) is "a reference to the collective opinion or satisfaction of the members of the Cabinet or that of a particular Minister to whom the Cabinet has delegated authority" (Vern, 2019).

An attempt was made in 1983 to shift this power to the PM by constitutional amendment but was later repealed. However, in 2016, a similar attempt was made and succeeded by the passing of National Security Council Act 2016 (NSC Act). This statute accords the power to declare an area of security to the Head of the National Security Council, who is the PM. In August 2020, the NSC Act Amendment was introduced to remove the above mentioned power from the PM. However, the twist was that section 18(1) of the NSC Act will grant the power to the King on the advice of eight members of the NSC chaired by the PM (Carvalho et 
al., 2020). This is a grey area in relation to the power granted to the YDPA 'on advice' by the PM under the NSC Act to declare emergency, dealing with the disaster management.

The main characteristics of Lockean legalism are listed in the following table and the Malaysian position on similar features are provided to determine the viability and availability in the Malaysian landscape.

TABLE 1: Adoption of Lockean Model

\begin{tabular}{l|ll} 
NO & LOCKEAN FEATURES & MALAYSIAN POSITION \\
\hline $\mathbf{1}$ & Institutional separation & Executive is part of Legislature \\
$\mathbf{2}$ & Executive discretionary power & Article $40(2)$, cf Article $40(1)$ and Article $40(1 \mathrm{~A})$ \\
$\mathbf{3}$ & Ruler prerogative & Article $150(1)$, Article $38(2)$, Article 130 \\
$\mathbf{4}$ & Purpose for public good & Article $150(1)$ \\
$\mathbf{5}$ & Public evaluation & Members of Parliament \\
$\mathbf{6}$ & Extra-constitutional method & Restricted by Article 4(1)
\end{tabular}

Table 1 shows that Lockean theory emphasised a certain discretionary power granted to the Executive if the state adopted institutional separation between Legislature and Executive. In addition, the discretionary power may be exercised "beyond legal boundary" (Locke, 1988). However, the Malaysian Parliament consists of Legislature and Executive that the latter tends to dominate the legislative process. The YPDA's main legislative role is to grant royal assent. Malaysia adopted a polyarchic structure (king in Parliament) which was the former English system before the British transformed to an absolute parliamentary sovereignty or a monocratic regime. Locke's Second Treatise established that a monocratic system is the king's prerogative power "contrary and beyond the law" to safeguard the salus populi and the constitutional order (Pasquino,1998).

The Malaysian sultanate is not only unique, but is one of the oldest, too. The sultanate system was a monochromatic one with a ruler at each state until the British made Malaysia a federation. The first draft of Malaysian constitution in 1956 diluted the power of the Malay Rulers that caused them to demand amendments to redefine their function and position in the state government and on issues of national interest (Fernando, 2014). The royal institution is known as the Conference of Rulers (COR) which plays an important role in bringing together the rulers and the ruled. The King is chosen by the COR adopting a rotational basis between the ruler of states in Peninsular Malaysia. COR is part of the Executive and one of the oldest as well as unique monarchy systems that has emerged and sustained from the Malacca empire till to date. The role of COR on emergency matters is consultative in the form of advice, caution and warning related to questions of national policy (Phang Chin Hock $v$ Public Prosecutor, 1980). The matters related to the COR requires the consent of the COR when they relate to alteration of state boundaries (Article 2(b)), rights of Rulers (Article 38(4)) and the nine topics in Article 159(5) of the Federal Constitution.

The Federal Constitution confers the YDPA an Executive authority under Article 39 but Article 40(1) states that the YDPA shall act on the advice of the cabinet. The Constitution further provides in Article 40(1A) that the YDPA is to act in accordance with advice, on advice, or after considering advice, the YDPA shall accept and act in accordance with such advice. At this juncture, it connotes that the discretionary power of the YDPA is not fully independent. It is within this uncertain parameter of constitutional power of the YDPA that His Majesty is accorded the power to declare a "state of emergency". This power has been discussed by many stakeholders that has later led to the question whether this power is a discretionary or 
non-discretionary power of His Majesty. There are basically two dominant interpretations of the power of YDPA to declare emergency. The first line of argument is strongly supported by Hickling (1975; as cited by Faruqi, 2013) and judicial interpretations in the cases of Madhavan Nair v Government of Malaysia (1975) and Public Prosecutor v Mohd Amin bin Mohd Razali (2002).

In the case of Madhavan Nair v Government of Malaysia (1975), then PM Tunku Abdul Rahman submitted in court that he personally presented the Ordinance to the YDPA for consideration and approval. The YDPA approved the promulgation of the Ordinance after considering the matter and satisfied with condition(s). The case of Public Prosecutor $v$ Mohd Amin bin Mohd Razali (2002) lends partial credence to this view (Faruqi, 2013). According to the High Court, if during the dissolution of Parliament there is no cabinet in existence to advise the King, then His Majesty is empowered to declare a state of emergency on his own (Faruqi, 2013). The appointment of a caretaker government who can advise YDPA on this matter will not be binding on the King.

The second view firmly suggested that all references to the YDPA in the Constitution should be defined to indicate that "YDPA acting on advice". This decision is based on Articles 40(1) and 40(1A) and strongly supported by judiciary in the cases as Stephen Kalong Ningkan $v$ Government of Malacca (1968); Madhavan Nair v Government of Malaysia (1975) and Teh Cheng Poh v Public Prosecutor (1979) (Faruqi, 2016).

Another grey area on this matter is the power granted to the PM under the National Security Council Act 2016 (NSC Act) to chair the members of National Security Council and to advise the YDPA in declaring emergency, dealing with a security crisis which arguably may be extended to include disaster management. The premier's power to determine the state of emergency was formerly concentrated under the NSC Act prior to the amendment.

It is interesting to note that in 2016, the COR requested for the then NSC Bill to be refined but to no avail. The COR deliberation was based on the Article 38(2) of the Federal Constitution whereby the COR is authorised to deliberate (involve in lengthy and careful consideration) under two circumstances, they are on matters of "national policy" (for example changes in immigration policy) and on "any other matter that it thinks fit". Whilst the former requires reference to Article 39 (3) for constitutional advice, the latter is a discretionary power (Perumal, 2020). Perumal submitted that the COR deliberation on "national policy" for NSC Act was limited. The COR may deliberate on "any other matter that it thinks fit" which is the issue related to NSC Act and whether the legislation affects any part of the Federal Constitution (2020). Furthermore, on the issue of constitutionality of the NSC Act, the judicial decision in the case of Anwar Ibrahim suggested that the YDPA may apply Article 130 whereby the federal court is required to pronounce an opinion on any question imposed to it by the YDPA (Perumal, 2020; Anwar, 2020). The constitutional supremacy regime in Malaysia exercises the judicial review process though with a small number of success. The judiciary has an institutional separation structure from the Legislature and Executive.

Lokean highlighted that the Executive power conferred to the government is solely for the benefit of the society and must be exercised by enacted legislation without exemptions (Locke, 1988). Table 1 emphasises that the prerogative power is equivalent to the discretionary control to decide on matters of public good beyond legal parameter. However, the ruler prerogative must not substitute the law with the royal's will. The dictation of prerogative power on royal grounds must be distinguished with the refusal to grant a decree for the people's good. The legitimacy of the discretionary power is confined within the public interest framework and resistance on this basis is allowed (Locke, 1988). 
The ruler's prerogative power is enshrined in the Malaysian constitution. This provision includes the phrase "a grave emergency exists whereby the security, or the economic life, or public order in the Federation or any part thereof is threatened". The conditions explained in the latter reflected the public good characters highlighted by Lockean. Drahos observed public goods consist of a wide feature which include those related to norms (peace, order, and good governance) and those largely classified under physical goods (forest and algae are few examples) (2004). In addition, public goods have two main features, they are non-rivalry (the consumption of a good, will not reduce availability of it for others) and non-excludability (the availability of a good, will not stop others from benefitting from it) (Pettinger, 2019). Environmental crises, particularly river pollution and haze hazard can easily fit in the parameter of public goods. In a post-disaster management case, a land allocation approach by the state government managed to address only $6 \%$ of the house construction at the affected area reflected a weak Executive policy on environmental hazards (Saraf et al., 2019). The ground for His Majesty to execute the emergency power lies in the existence of situations where he thinks grave emergencies exist including public goods. Considering the above discussions, the phrase "a grave emergency exists" has undergone expansion of interpretation from communist threat to intoxicated air.

Table 1 also shows an exquisite character of Locke prerogative i.e., allowing the public assessment and making a distinction between parental and political power with the public playing an important role at an ex-post position (Locke,1988). It provides a political and institutional safeguard against the abuse of power (Sharon, 2019). On a different note, local community involvement plays an important role in "protecting communities from hazards and minimising their vulnerability to the risks of disaster" (Zubir \& Amirrol, 2011). This aspect is lacking in the Malaysian scenario unless members of Parliament of lower house or House of Representative are considered as representatives of the people and connotes a public assessment. The approval of motion by the House of Representative (Dewan Rakyat) on the Sungai Kim Kim chemical dumping incident may represent the voices of the people but was refused by the government. This incident may result from the lack of a clearer guideline to declare emergency by the Executive according to Lockean "salus populi suprema lex" (Locke, 1988). Based on this situation, the question is whether there is a possibility for the YDPA to announce an emergency even if the PM does not advise? The above mentioned cases are referred to and the judiciary decided that the YDPA's emergency power under Article 150(1) must be read with Article 40(1) and 40(1A) that impose a duty to act on advice (Faruqi, 2013). Another Lockean feature stated in Table 1 is the public participation involves the preference of an emergency power being employed in an extra-constitutional nature and the public understood the extraordinary character of the action and justified the position as in line with the Constitution and accepted the normalisation process (Tushnet, 2005). Locke highlighted that "they shall be governed by declared laws, or else their peace, quiet, and property will still be at the same uncertainty as it was in the state of nature" (1988). In addition, the parameter of Lockean prerogative is far-reaching traditional war-related emergencies and "as an extra-legal bureaucratic power drives neoliberal policy toward the poor and displaced" (Arnold, 2005). This aspect is limited in Malaysia as the Federal Constitution provides for Article 4(1) as the highest law of the land. Applying the Lockean legalism model, the YDPA may explore the provision of Article 150(1) as His Royal Highness discretionary powers to act beyond the constitutional nature as an extraordinary matter due to an environmental disaster that falls under the category of public goods. 
Considering the above discussions and in the context of the environment crisis, it is suggested by Lockean legalism that the adoption of public goods argument allowed the King's prerogative to act on an extra-constitutional nature. Hence, the proposed measure is the judicial interpretation of Article 40(2) and Article 130 to empower the Monarch in this context.

\section{Conclusion}

This study critically analysed the significant role of YDPA in declaring "state of emergency" to safeguard public safety in the context of environment and climate domain and examined the emergency powers of His Majesty to proclaim emergency. The Lockean emergency model highlighted six important characteristics, they are institutional separation, executive discretionary power, ruler prerogative, purpose for public good, public evaluation and extra constitutional nature. The research employed the Lockean mechanism in understanding the power to proclaim emergency in the environmental crisis.

The practice of constitutionalism is crucial in a parliamentary democracy country such as Malaysia. Adoption of Lockean features in interpreting the extensive power of Executive is hoped to enlighten the YDPA role to "satisfy a grave emergency exist" to proclaim emergency in river pollution and haze hazard situations. Article 40(2) provides an implied discretionary power for the YDPA to act in his discretion in "any other case mentioned in this Constitution" can be argued to include the environmental crisis under the premise of Lockean public good interpretation. The COR may enhance and empower the YDPA's function by deliberating on any other matter that it thinks fit and may advise, caution and warn on issues related to the environmental crisis under Article 38(2). Within this limited constitutional parameter, the YDPA may invoke Article 130 to request the judiciary to pronounce an opinion on matters related to the deliberation of the COR and may be extended to include "a grave emergency exists".

\section{Acknowledgements}

The authors gratefully acknowledge the help of the Kursi Institusi Raja-Raja Melayu (Institution of Malay Rulers Chair) in providing the Kursi Institusi Raja-Raja Melayu Fund (Project Number: 600/RMC/LESTARI 5/3 (004/2020) research grant, the Research Management Centre (RMC) of Universiti Teknologi MARA for assisting the process and Office of Research Nexus UiTM (RENEU) for organising a workshop on writing skill on 14-15 September 2020, at Institute Kepimpinan dan Pembangunan (ILD), Bandar Enstek, Negeri Sembilan, Malaysia. The authors are also thankful to the Faculty of Law, Universiti Teknologi MARA for supporting the research activities.

\section{References}

Annuar, A. (2019). Putrajaya not declaring emergency over Pasir Gudang toxic fumes. [online] Available. The Malay Mail.

https://www.malaymail.com/news/malaysia/2019/03/14/putrajaya-not-declaringemergency-over-pasir-gudang-toxic-fumes/1732660

Arnold, K. (2005). Domestic War: Locke's Concept of Prerogative and Implications for U.S. 'Wars' Today. Polity, 1-28.

Bossuet, J. B. (1707). Bossuet: Politics Drawn from the Very Words of Holy Scripture. In

Riley, P. (1990). Cambridge Texts in the History of Political Thought. Cambridge, UK: Cambridge University Press. 
Bulmer, E. (2017). Constitutional Monarchs in Parliamentary Democracies. International Institute for Democracy and Electoral Assistance (International IDEA). https://www.idea.int/sites/default/files/publications/constitutional-monarchs-inparliamentary-democracies-primer.pdf.

Carvalho, M., Sivanandam, H., \& Rahim, R. (2019). Dewan Rakyat approves motion to declare state of emergency over Pasir Gudang chemical dump. The Star. https://www.thestar.com.my/news/nation/2019/03/14/dewan-rakyat-approvesmotion-to-declare-state-of-emergency-over-pasir-gudang-chemical-spill/.

Carvalho, M., Sivanandam, H., \& Rahim, R. (2020). Dewan Rakyat passes amendments to National Security Council Act 2016, removing PM's power to declare security zone. The Star. https://www.thestar.com.my/news/nation/2020/08/24/dewan-rakyat-passesamendments-to-national-security-council-act-2016-removing-pm039s-power-todeclare-security-zone.

Datuk Seri Anwar Ibrahim v Government of Malaysia \& Anor. 4.M.L.J.133. (2020).

Drahos, P. (2004). The Regulation of Public Goods. Journal of International Economic Law, 7(2), 321-339.

Devi, V. (2019). Sg Kim Kim victims file RM30mil suit against Federal, state governments and 10 others. The Star.

Dzulkifli, F., \& Zameri, M. N. (2016). e Functions of Constitutional Monarchy in Malaysian Political System: The Perceptions of Malay Community. Seminar on National Resilience. Political Managements and Policies in Malaysia. https://core.ac.uk/download/pdf/12118572.pdf

Faruqi, S. S. (2013). Emergency Powers of the Monarch. The Malaysian Bar. https://www.malaysianbar.org.my/article/news/legal-and-general-news/legalnews/emergency-powers-of-the-monarch.

Faruqi, S. S. (2016). Controversy surrounding NSC Act: Despite his general duty to act on advice, the King retains some discretionary powers. The Star. https://www.thestar.com.my/opinion/columnists/reflecting-on-thelaw/2016/09/01/controversy-surrounding-nsc-act-despite-his-general-duty-to-act-onadvice-the-king-retains-some-disc/

Fernando, J. M. (2014). Defending the monarchy: The Malay rulers and the making of the Malayan constitution, 1956-1957. Varia, 88, 149-167.

Jenkins, D. (2011). The Lockean Constitution: Separation of Powers and the Limits of Prerogative, 56 (3). McGill 543. https://id.erudit.org/iderudit/1005132ar.

Hickling, R. H. (1975). The Prerogative in Malaysia. Malaya Law Review, 17(2), 207-232.

Lloyd, S. (1992). Hobbes's absolutism. In Ideals as Interests in Hobbes's Leviathan: The Power of Mind over Matter, 289-321. Cambridge: Cambridge University Press.

Locke, J. (1988). Two Treatises of Government. In P. Laslett (Ed.), Cambridge Texts in the History of Political Thought (pp. 265-428). Cambridge University Press.

Montesquieu: The Spirit of the Laws. (1989). In A. Cohler, B. Miller, \& H. Stone (Eds.), Cambridge Texts in the History of Political Thought. Cambridge University Press.

Madhavan Nair v Government of Malaysia, 2.M.L.J.286. (1975).

Pasquino, P. (1998). Locke on King's Prerogative, Pol. Theory, 26, 198-208.

Perumal, P. (2020). King may refer constitutionality question to Federal Court. The Malay Mail.

Phang Chin Hock v Public Prosecutor, 2.M.L.J.213.(1980).

Public Prosecutor v Mohd Amin bin Mohd Razali \& Ors, 5.M.L.J.406. (2002). 
Saraf, M., Mohd, T., Nordin, S., \& Abdullah, M. (2019). The Applicability of Land Allocation Approach For Post-Disaster House Construction in Kuala Krai. Planning Malaysia: Journal of the Malaysian Institute of Planners, 17(1), 205-218. https://www.planningmalaysia.org/index.php/pmj/article/view/599

Sharon, A. (2019). Locke, liberty, and law: Legalism and extra-legal powers in the Second Treatise. European Journal of Political Theory.

Smith, S. (1995). British Relations with the Malay Rulers from Decentralization to Malayan Independence 1930-1957. Oxford University Press.

Stephen Kalong Ningkan v Abang Openg and Tawi Sli, 2.M.L.J. 238. (1968).

Stephen Kalong Ningkan v Government of Malacca, 1.M.L.J.119. (1968).

Teh Cheng Poh v Public Prosecutor, 1.M.L.J.50. (1979).

The New Straits Times. (2019). Malaysian's Monarchy: One of Worlds' Oldest. The New Straits Times.

History Behind the Malaysian Monarchy. (2010). The Star. https://www.thestar.com.my/news/nation/2010/06/05/history-behind-themalaysian-monarchy

Tushnet, M. (2005). Emergencies and the Idea of Constitutionalism, 50. In Tushnet, M. (2005). The Constitution in Wartime. Durham, NC: Duke University Press.

Vern, W. T. T. (2019). Subversion and Emergency Powers. Malayan Legal Journal, 4, Ixxiii, Ixxiv-Ixiv.

Winstedt, R. (1968). A History of Malaya, 224-240. Kuala Lumpur: Marican \& Sons Ltd.

Zubir, S., \& Amirrol, H. (2011). Disaster risk reduction through community participation. WIT Transactions on Ecology and the Environment, 195-205. 